\title{
EAMR
}

European Accounting and

Management Review

\section{Economic consequence of accounting standards in the hotel industry: lobbying arguments versus expected impact}

\author{
Núria Arimany-Serrat \\ Universitat de Vic \\ Àngels Fitó \\ Universitat Oberta de Catalunya \\ Neus Orgaz-Guerrero \\ Universitat Oberta de Catalunya
}

Received November 20, 2015; accepted November 26, 2015.

\begin{abstract}
Accounting standards generate economic consequences that can be either intended or unintended. European and US accounting regulators have proposed to capitalize operating leases so that future payments derived from lease contracts are accounted for as debt. As operating leases are an important source of funding for the hotel industry, the sector has lobbied against the proposal. This paper analyses the economic impact on the hotel business of operating lease capitalization, using both hotel operators' perceptions and quantitative analyses of the expected consequences. Results show that the arguments presented in the hotels' comment letters are confirmed by the impact predicted. While hotels do not believe that the new standard will improve financial information quality (the intended economic consequence), they expect an increase in debt and reduced profitability (the unintended economic consequences), which may affect their strategies. An early response to this new standard is proposed in order to avoid unintended effects.
\end{abstract}

\section{KEYWORDS}

Operating leases, hotels, economic consequences, business strategy, lobby. 


\section{Introduction}

Accounting standards generate economic consequences that can be either intended or unintended depending on whether they are aligned with the financial information objectives explicitly stated by accounting regulators (Brüggeman et al., 2013). Intended consequences are those that contribute to the consolidation of the qualitative characteristics of financial statements, like relevance or comparability. These are desirable and are expected to increase the quality of financial information. Unintended consequences impinge upon the contractual role of accounting - the way companies and stakeholders define their relationships. A new accounting standard may thus lead to changes in the way parties react and contract. These unintended consequences are generally supplementary to the first and can have a negative impact on, for example, companies' financial performance, access to financing, relative position in the market and, ultimately, business strategies.

One of the current proposals for a new accounting standard concerns operating leases. ${ }^{1}$ Operating leases are an expense for the lessee and therefore affect the net income of the company in the year they are accrued. However, there is no balance sheet recognition for operating leases because future payments are not recorded as debt. Regulators are proposing that operating leases be capitalized and be included in the balance sheet, both as an asset (i.e. right of use asset) and a liability (including the present value of the future payments committed to today).

Lease contracts are becoming increasingly common in the lodging industry (Whittaker, 2008, Koh \& Jang, 2009). Whittaker shows how the sale and leaseback transactions of hotel portfolios have recently become a prominent part of financing and property ownership arrangements in the UK. The hotel industry has certain peculiarities that affect the hotel operator (the lessee), such as the integral role of property in basic transactions and the consequent interaction between customer and property. Upneja and Dalbor (2001) show how equipment leasing (as opposed to an outright purchase) has increased dramatically in the US. Given leasing's important role in hotel strategy, it is important to

\footnotetext{
${ }^{1}$ There have been two Exposure Drafts (ED) issued by IASB and FASB (European and US accounting regulators) regarding operating leases, a first one on August 2010 and a second one on May 2013. Feedback sent by users and preparers after the first one was very significant and therefore the regulators decided to issue the second. The basic idea of capitalization is maintained in both although in the second one alternative income statement recognitions are proposed depending on the type of asset leased.
} 
evaluate the potential impact of the new standard as well as its consequences (both intended and unintended) for hotels' financial performance, capital structure, and strategies. This paper analyses the following research questions:

a) Analyzes the economic impact operating lease capitalization will have on hotels' business position and strategies from an ex ante perspective using hotel operators' comment letters,

b) An analysis of their financial statements. If the capitalization of operating leases will have a significant effect on the financial ratios of hotels industry.

c) The paper also discusses the possible impact on hotel management and decision making.

As this study represents ex ante research (Schipper, 1994), it cannot move beyond an analysis of the effect (perceived vs. expected) of the new standard. However, if a (qualitative) perceptions analysis, together with a (quantitative) expected impact assessment, indicates that debt positions and financial performance will be affected, we can expect the standard to have ex post consequences for capital structure strategies in the hotel industry. Debt, liquidity and profitability measures, would be substantially affected should those payments be considered as debt. The effect on gearing ratios is particularly important, as this could seriously affect debt covenants hotel's financial position, and, in the end, their reputations.

The relevance of this issue is evidenced by the great number of letters, over 1000, sent to regulators by the parties affected by the proposal. Big players in the accommodation sector have participated ${ }^{2}$ in this so-called 'lobbying' process in an attempt to influence regulators' final decision. Most hotels do not support the proposal because of the intended and unintended (as well as merely undesirable) consequences they anticipate. They argue that important financial information characteristics like reliability and comparability may be damaged and that financial performance measures may be compromised. The issue of comparability is of particular interest here since the accommodation sector's use of leases and management contracts instead of financial debt places hotels into a unique financial position.

\footnotetext{
${ }^{2}$ Among the hotel groups that have participated in the discussion are Hotrec (Belgium), Hilton and Hyatt (US), Mandarin Oriental (Hong Kong), Intercontinental Hotels Group (UK), and NH (Spain)
} 
The literature on the economic consequences of accounting standards and the expected impact of the operating leases proposal (Fülbier et al., 2008; Singh, 2012; Fitó, et. al., 2013) shows that the effect on the financial performance of affected companies is expected to be significant, in particular for the retail industry. However, to our knowledge, no study has compared the perceptions of the hotel industry (as expressed in the comment letters) to the expected impact measured through empirical analysis. Using the comment letters as a source of information about perceptions of the impact and conducting an analysis of the 'real' expected impact provide our study with a new and very 'close to business' approach.

To analyze the effect of the operating leases capitalization and hotel industry perception is important for their management. In recent years, most of the hotel chains have continued to expand the business model to differentiate the entity that owns the property and the management of the company, which is contextualized in a lease business contract. For this reason, the amount of operating leases in the hotel industry is important in its capitalization and financial statements can have a big impact...

The results of the paper show that the perceptions and arguments proposed in the comment letters reflect the significant economic impact expected to hit the lodging industry: debt ratios increase significantly while performance ratios are also affected. Hotel lobbying thus appears to be justified by the undesirable effects anticipated by this analysis. This paper shows how the new accounting standard will generate economic consequences that may modify hotels' capital structure and affect their future strategy. The rest of this paper is organised as follows. Section 2 analyses the content of the comment letters. Section 3 reviews the literature and develops the hypothesis. Section 4 presents the results. Finally, Section 5 concludes with some policy implications and the limitations of the study. 


\section{Comment Letter's Content Analysis: The perception Approach}

\subsection{Data and Methods}

We have conducted a two-step content analysis of the nine comment letters submitted by hotels in response to the regulators Exposure Drafts (ED). Content analysis is considered useful for organizing text into manageable units, facilitating research (Weber, 1990; Beck et al.,, 2010; Giner \& Arce, 2012). The average comment letter analysed and coded was approximately nine pages (they ranged from three to 17). The nine comment letters total 81 pages of comments. Five letters are European, three are from the US, and one is from Asia.

In the first step, and following the lobbying literature, we categorize hotels based on their general position on the proposed changes (Yen et al., 2010; Giner \& Arce, 2012). Although any of the comment letters can be considered as supporting the ED, some express a general agreement with their objective: they agree with the right-of-use method but present relevant objections to the proposal requirements. After a first analysis of the full set, we classify the letters into three categories: 'Support', comprising hotels that do not express disagreement with the ED and who support the right-of use model while providing light objections; 'Partial Support', comprising hotels that do not express disagreement with the ED and who support the right-of-use model but who also have consistent objections to the proposal; and 'Detractors', composed of hotels that express disagreement with the ED and that do not agree with the right of use model. Three comment letters are classified as Partial Support while six are considered 'Detractors'.

In the second step of our analysis, we consider each of the arguments proposed in the comment letters in order to perform a deeper study of industry perceptions. As stated by Georgiou (2004), comment letters appear to be a good proxy for other, less overt, lobbying methods. Most of the hotels' arguments refer to the economic consequences of the proposed standard and, following the classification in Brüggemann et al., (2013), we have divided the arguments into those discussing intended economic consequences and those discussing unintended ones. This categorisation has also been used in the literature, but we have adapted it to the particularities of the hotel industry. The intended consequences are those impacting the informational characteristics of financial reporting (which are expected to improve through the new standards), while unintended consequences are those derived from the contractual role of accounting - the relationship between the entity and third parties. We have also considered a third category, which 
includes technical questions regarding methodology or the criteria outlined by the proposal.

\subsection{Results}

Our initial results produce the following:

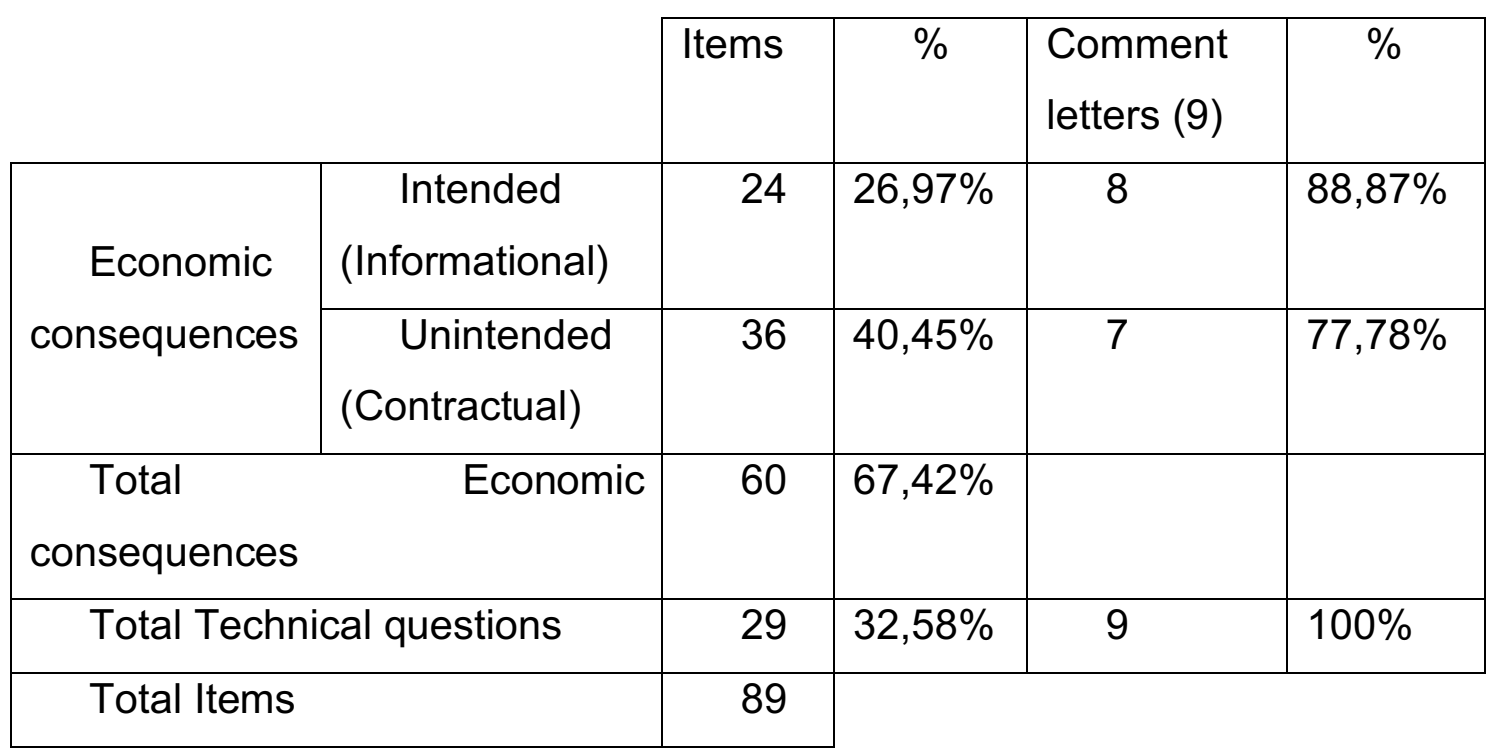

Table 1: Content Analysis of Hotels' Comment Letters

The items (arguments) offered by the hotels total 89, 60 (67\%) of which can be classified as referring to economic consequences. When classifying them into intended and unintended groups, we see that $27 \%$ belong to the former and $40 \%$ to the latter. Therefore, the biggest concern of the hotel industry is the unintended impact of the proposed standard. When we classify the arguments by number of companies, we see that seven out of nine referred to either the unintended or intended economic consequences while all also made some reference to technical questions. Particularly interesting is how hotels perceive the potentially negative effect on the informational characteristics of hotels' financial reporting: they believe the intended consequences will be negative, providing us with our first relevant conclusion. Regulators issue new proposals in the expectation of causing positive effects on the qualitative characteristics of financial information, of enhancing items such as comparability or reliability. However, we observe that hotels do not perceive this positive effect, suggesting that the very first objective of this accounting regulation change would not be met. As for the unintended consequences, we would expect them to have a negative effect and therefore be undesirable. The analysis of the 
comment letters confirms this expectation, as hotels expect the proposal to have damaging effects on their financial performance.

It is worth noting that six out of the nine comment letters analysed express explicitly that the ED is particularly harmful for the hotel industry because of the characteristics of the contracts commonly used in it. For example, Host Hotels responded as follows:

"Hospitality's entities sign leases for many various economic opportunities (in particular to benefit from flexibility). Consequently, the project does not traduce the economic reality of the contracts as assuming that any lease is a financing of the purchase of an asset, which we consider to deny the economics of many of these arrangements" The Mandarin Oriental Group responded this way:

"The proposed changes in the exposure draft do not reflect the underlying economic substance of hotel lease arrangements".

The HOTREC association stated the following:

"We would like, in particular, to raise the concerns of the European Hospitality industry regarding some of the changes in lease accounting that are proposed by the IASB. In particular, HOTREC considers that the proposed abolition of the distinction between 'finance lease' and 'operating lease' would have severe consequences for the hotel industry".

If we analyse the letter contents and the relative weights given to the effects of the standard, we see the following: 


\begin{tabular}{|l|c|c|c|}
\hline & Items & $\begin{array}{c}\% \text { s/Comment } \\
\text { letters (9) }\end{array}$ & $\begin{array}{c}\% \mathrm{~s} / \\
\text { Items (24) }\end{array}$ \\
\hline Comparability & 4 & $44,44 \%$ & $16,66 \%$ \\
\hline Transparency & 1 & $11,11 \%$ & $4,17 \%$ \\
\hline Usefulness & 1 & $11,11 \%$ & $4,17 \%$ \\
\hline Subjectivity & 7 & $77,78 \%$ & $29,17 \%$ \\
\hline Reliability with the hotel lease \\
arrangements
\end{tabular}

Table 2: Intended Economic Consequences (6 items)

As refereed before, to summarize or organize the intended or unintended consequences we refer to the work of Brueggemann et al. (2013). These authors built a compilation of the literature on the economic consequences of IFRS implementation and classified into two main groups: intended consequences and unintended consequences.

The expected consequences would be, according to the authors, those that regulators "expect", those derived from the conceptual framework of accounting rules, those concerning the fundamental characteristics or quality criteria to be accomplish by the accounting information and that would be improved with the new proposal.

Table 2 illustrates the informational characteristics the hotel industry believes will be damaged. Regarding intended consequences, the most frequent argument is that the change will add subjectivity to the financial statements because it includes many judgments, assessments, and reassessments. Regarding reliability, six hotels consider that the ED does not fit with the special characteristics of the lodging industry. The need to be consistent with other standards in the definition of assets and liabilities is also argued in five of the nine letters. Additionally, comparability, one of the expected benefits of the new accounting rule, is not appreciated; on the contrary, the companies argue that some identical operations can be considered in different ways depending on interpretations of the rule. We see, then, that relevant financial reporting characteristics are expected to be 
degraded together with an increase in subjectivity. Seven hotels also complain that annual reports will lose their informational power, meaning that the intended increase in quality will not occur.

We have also coded the letters' content regarding unintended economic consequences, as shown in Table 3 below.

\begin{tabular}{|l|c|c|c|}
\hline & Items & $\begin{array}{c}\% \text { s/Comment } \\
\text { letters (9) }\end{array}$ & $\begin{array}{c}\% \text { s/ Items } \\
(36)\end{array}$ \\
\hline Complexity & 4 & $44,44 \%$ & $11,11 \%$ \\
\hline Cost outweigh benefits & 5 & $55,56 \%$ & $13,89 \%$ \\
\hline $\begin{array}{l}\text { Increase leverage ratios/worse } \\
\text { ratios }\end{array}$ & 3 & $33,33 \%$ & $8,34 \%$ \\
\hline Availability of credit & 3 & $33,33 \%$ & $8,33 \%$ \\
\hline Liquidity ratios & 2 & $22,22 \%$ & $5,56 \%$ \\
\hline Debt covenants & 1 & $11,11 \%$ & $2,78 \%$ \\
\hline Classification of expenses & 1 & $11,11 \%$ & $2,78 \%$ \\
\hline EBIT and EBIDTA would & 1 & $11,11 \%$ & $2,78 \%$ \\
\hline change & 4 & $44,44 \%$ & $11,11 \%$ \\
\hline Volatility & 1 & $11,11 \%$ & $2,78 \%$ \\
\hline Stock exchange rating & 5 & $55,56 \%$ & $13,89 \%$ \\
\hline Renewal option & 6 & $66,67 \%$ & $16,67 \%$ \\
\hline Inclusion of contingent rent & 36 & & \\
\hline Total Items & 9 & & \\
\hline Number of comment letters & & & \\
\hline Table 3 Unintended Econo & & \\
\hline
\end{tabular}

Table 3: Unintended Economic Consequences (13 items)

The unintended consequences, however, have received less attention and, in our view, should be taken into account more now than ever, given the economic circumstances. The group of unintended consequences deeply considered by the literature are fundamentally economic and can be derived, for example, in changes in the relative position of the companies in terms of indebtedness, creditworthiness or performance. As Fulbier research (2008) shows us, in a study for German companies, such as the introduction of this rule would impact on the level of indebtedness and profitability of the companies 
analyzed, affecting their ability to borrow, its financial situation and both its relative market position and image to analysts and investors. They produce here an "informational" improvement effect by the inclusion of such leases in the balance sheet but also some unexpected consequences and also unwanted.

The gravest balance sheet concern is the impact on gearing ratios and the consequences for debt availability, debt covenants, and even stock exchange ratings. Eighteen of the letter items could be considered debt-related (e.g. those concerning increased leverage ratios, credit availability, debt covenants, renewal options, and contingent rents), with an aggregated result of almost $50 \%$ of the total. The major concerns about the income statement are the changes in classification and expense amounts, with the subsequent changes in EBIT and EBIDTA and consequent result volatility. Complexity, the accounting cost, and the acknowledgement that the implementation costs will outweigh the benefits to the quality of financial information are major arguments included in five of the nine comment letters. Overall, the industry displays a clearly negative perception of the proposal's unintended consequences for hotels' economic and financial performance and, in particular, for their increased debt positions and related effects.

We thus conclude that most comment letters argue against the proposal and consider that the new accounting rules ignore the economic reality of hotel contracts. The letters argue that the ED makes the financial statements less comparable, reliable, and consistent because of the uncertainty in their definitions and scope. Negative economic consequences are expected because of the increased leverage ratios and the changes in earnings before interest and tax (EBIT) and earnings before interest, tax, depreciation, and amortisation (EBITDA). Finally, hotels also consider that the change would entail a substantial increase in costs and complexity for preparers and request a deeper analysis of the implications of ED implementation. 


\section{Assessment of the Impact: A Quantitative Approach}

Decisions about financing, investing, and profitability are important in hotel strategies (Hesford \& Potter, 2010, Tsai et al., 2011), and the proportion of debt to equity is a key factor in the performance of hotels and restaurants. Authors such as Madan (2007) have examined the role of financing decisions in the overall performance of hotel chains based on an analysis of their debt to equity structure. Building on the idea that neither high nor low debt-equity ratios are desirable and assuming that financing is a very subjective decision and a function of multiple factors, Madan (2007) shows that hotels with a low share of capital but high reserves and debt should either use their accumulated profits or issue fresh capital to execute an expansion. Alternatively, hotels with low debt levels and high equity should consider issuing more debt and increasing their gearing level in order to finance future growth. The author finds that, from the financial perspective, capital structure is one of the most important determinants of a company's sustainable growth. He also analyses the role of leverage as a key determinant, finding it to affect some companies positively and others negatively. Jung (2008) proposes using the weighted average cost of capital as a driver for performance, thus also incorporating debt as a key indicator. Upneja and Dalbor (2001) and Dalbor and Upneja (2004) reveal relationships between debt and growth and between debt and financial risk. The aforementioned papers all show the relevance of accounting metrics in hotel performance.

Regarding profitability, Hernandez-Lara et al., (2012) categorize accommodation firms into representative groups according to their economic profitability. Profitability, considered a key measure of efficient management, can be measured through various ratios. Hernandez-Lara et al., (2012) use three different metrics to measure profitability, each using accounting and financial information. Studies related to management and strategic analyses discuss key accounting figures such as debt and profitability as being highly relevant. Harrison (2003), who proposes a model for strategic analysis in the hospitality industry (understood as the systematic investigation of a firm and its environment), refers to financial resources as a key variable in the model and specifies that ratios like return-on-assets and debt-to-total-assets offer a good barometer by which to assess the financial health of a hotel. Finally, and for efficiency purposes, corporate performance indicators have been shown to be relevant (Parte \& Alberca, 2013). Thus, the literature indicates that leverage and profitability ratios are often used to assess the current and future viability of hotels. In this sense, debt is one of the accounting figures commonly used in analysis, valuation, and viability assessments. 
A stream of research particularly relevant to our study is that dedicated to the role of leases in the hospitality industry. In studies like Whittaker (2008), we learn how sale and leaseback have become major financing methods in the hotel industry in the UK over the last 10 years. The most significant leases, hotel and land leases, are long term (20 to 100 years, sometimes including renewal options), and typically include contingent rents based on hotel profits. Koh and Jang (2009) investigate the determinants of using operating leases in the hotel industry. They claim that operating leases have been used not only for equipment but also as a financing instrument. The use of leases as a financing instrument is precisely one of the arguments urged by regulators when supporting the inclusion of future lease payments in hotels' balance sheets as debt (i.e. 'if they are a financial liability like debt, why shouldn't they be included as debt?')

A second body of literature that we build upon to construct our hypothesis is that regarding the economic consequences of accounting standards. A relevant paper in this area is Brüggemann et al., (2013), which classifies the economic consequences of accounting standards into intended and unintended categories. The intended consequences are those expected by regulators, like increased transparency, relevance, and comparability. The unintended consequences are those that have effects above and beyond those predicted by regulators and intense impacts on users and preparers. The proposal to include future lease payments in the balance sheets is expected to have positive consequences but may also lead to unexpected ones related to the hotels' business and even to changes in the companies' relative market positions. Many transformations have occurred in the accounting standards-setting process since authors like Zeff (1978) first used the term 'economic consequences of accounting regulation'. However, the issue remains the same: if we accept that accounting standards are bound to induce wealth distributions, analysing their consequences is necessary. Papers like Fülbier et al., (2008) and Singh (2012) show that the unexpected impact of changes may be significant for key ratios, debt covenants, and financing requirements.

Following the literature and through our analysis of the comment letters, we expect that the inclusion of future lease payments in hotels' balance sheets will have a significant effect on hotels' financial positions. We thus propose the following hypothesis:

H1: There are significant differences between financial ratios of the hotel groups under study before, and after, the operating lease capitalization. 


\subsection{Data and Methods}

We selected hotels in Europe using data contained in DataStream. We found 25 hotels in the database, but only 10 of them disclose information on future operating lease payments in the notes. ${ }^{3}$ Information on payments has been manually collected from those notes. The period of analysis covers 2005 to 2011, for an imbalanced panel 64 observations. This period is used because all companies were made to disclose their commitments regarding leases in the notes starting in 2005, and 2011 was the last year available when the information was being collected.

The operating lease information found in the notes is a schedule of future payments disclosed separately in three different figures:

a) Payments due the year after reporting

b) Payments due two to five years after reporting

c) Payments due after five years

We also collected accounting numbers and other information like the hotel-specific weighted interest rate for the recognized debt and the effective tax rate. However, these data were not always disclosed by the firms. Other information that would make the capitalization procedure (i.e. the simulation of including future payments as debt) more accurate, such as the categories of the assets rented, the assets' useful lives or lease period, or the weighted average implicit interest rate for each firm's portfolio of operating leases, were not disclosed by most of the companies selected. ${ }^{4}$ Hence, the limited availability of

\footnotetext{
${ }^{3}$ There is an important body of literature dedicated to compliance with accounting regulations (Street \& Gray, 2001, 2002; Robinson et al., 2011; Depoers \& Jeanjean, 2012). Although it is not the objective of our study to detail the reasons why companies disclose or fail to disclose information regarding leases, there seems to be a certain time lag between new standards and compliance. We have studied whether this happens in the accommodation sector. Disclosing those future payments in the notes became compulsory in 2005. We have observed that fewer hotels disclosed this information in the first years of our analysis than at the end of the period. It is expected, then, that hotels increased the level of their disclosure of those relevant items later on.
}

\footnotetext{
${ }^{4}$ This is a limitation of our analysis. However, companies do not disclose this type of information in their annual accounts. Unfortunately, then, we were not able to perform a more detailed analysis that would distinguish among effects based on types of assets rented.
} 
public domain data makes it necessary to introduce some assumptions based on the literature.

Although the appropriate interest rate could be the implicit weighted average rate for each firm's portfolio or the implicit rate in the firms' capital leases, these data were not voluntarily disclosed by most of the hotels. In their absence, most studies chose a fixed discount rate for the complete sample (Imhoff et al., 1991; Ely, 1995; Beattie et al., 1998; Fülbier et al., 2008). However, we find the use of a fixed interest/discount rate for all companies too rigid. Thus, following Damodaran $\left(2012^{5}\right)$, we have estimated a discount rate for each company, which is, in our opinion, more accurate. To do so, we have added to the general reference interest rate in Europe a firm-specific risk premium based on the firms' interest coverage ratio (Interest expenses/EBIT).

Regarding the leases' contracts useful lives at the time of capitalization, Imhoff et al. (1991) assume that, for a company with a stable portfolio of leases, the breakeven point where the periodic capital leases expenses equal the periodic operating lease expenses is $50 \%$ of the way through its life. In line with this hypothesis (Ely, 1995; Bennet \& Bradbury, 2003; Fülbier et al., 2008), we consider that the ratio of completion of the lease contracts at the capitalization moment was 50\%. This assumption entails that the effect on the current period's income of the constructive capitalization is minimal. ${ }^{6}$ Finally, and in relation to the tax rate, we calculate the average effective tax rate for each year by dividing the taxation by the earnings before taxes.

Our procedure is based on the constructive capitalization model in Imhoff et al. (1991, 1997), which simulates the effects of operating lease capitalization on assets, liabilities, equity, and the related income statement positions. The literature has considered the constructive capitalization model (Fulbier et al., 2008; Beattie et al., 1998; Fitó et al., 2013) because it is a more developed methodology than is the alternative, the factor method. The main difference between them is that the former considers the potential

\footnotetext{
${ }^{5}$ http://pages.stern.nyu.edu/ adamodar/

${ }^{6}$ This is of particular interest to our study given that one of the claims in the comment letters was that the impact on the income statements was minimized. Our estimation may thus be closer to the future definite change in regulation.
} 
effect in equity and net income while the latter ignores it. The factor method is especially useful for practitioners because of its simplicity and ease of application. ${ }^{7}$

To analyse the impact of lease capitalization on financial statements and to facilitate comparison with previous studies (Beattie et al., 1998; Fülbier et al., 2008), we calculate eight financial ratios (Gallizo, 2005). In the first group of ratios, related to the presentation of items in the balance sheet, we include a first set of ratios linked to leverage in order to measure the changes in the companies' financial leverage position caused by the increased lease liability. These are the equity to assets (LEV1), equity to liabilities (LEV2), current liabilities to non-current liabilities (LEVQ), and financial leverage (FINLEV). We also include the liquidity ratio (LIQ), which compares current assets with current liabilities, and the non-current assets turnover (NCAT), which divides sales into non-current assets.

Although we consider the minimal effects of the constructively capitalizing method on the income statement, mainly due to the assumptions of our model, the impact on the balance sheet could alter the commonly used profitability ratios. We calculate both return on assets (ROA) and return on equity (ROE), as these measures strongly influence financial analysis; any alteration in them could affect the diagnosis of a firm's performance evolution. Considering the modifications on the balance sheet, the capitalization of operating leases will systematically result in a bigger denominator (total assets) in the case of ROA and a smaller denominator (shareholders' equity) in the case of ROE. The impact in the numerator is not expected to be significant; given our assumption that the residual life of the lease contract over its total life is equivalent to $50 \%$ and that this is the moment when no impact on the income statement is felt.

In Table 4, we show the ratios considered in our analysis:

\footnotetext{
${ }^{7}$ Moody's, one of the most relevant analysts in the international markets, always uses the factor method when considering the need to make this adjustment to consolidated financial statements, which is, in our opinion, not as accurate as the capitalization method.
} 


\begin{tabular}{|c|l|l|l|}
\hline Ratio & Variable & \multicolumn{1}{|c|}{ Numerator } & \multicolumn{1}{|c|}{ Denominator } \\
\hline Leverage 1 & LEV1 & $\begin{array}{l}\text { Total } \\
\text { Liabilities }\end{array}$ & $\begin{array}{l}\text { Total equity }+ \text { total } \\
\text { liabilities }\end{array}$ \\
\hline Leverage 2 & LEV2 & Total Equity & Total Liabilities \\
\hline Debt quality & LEVQ & $\begin{array}{l}\text { Current } \\
\text { Liabilities }\end{array}$ & Non-current liabilities \\
\hline Financial leverage & FINLEV & $\begin{array}{l}\text { Total Assets x } \\
\text { EBT }\end{array}$ & Total Equity x EBIT \\
\hline Liquidity & LIQ & Current Assets & Current Liabilities \\
\hline Non-current assets & NCAT & Total Sales & Non-current Assets \\
\hline turnover & & & \\
\hline Return on Assets & ROA & EBIT & Total Assets \\
\hline Return on Equity & ROE & Net Income & Total Equity \\
\hline
\end{tabular}

Table 4: Ratio Definitions: ratios related to the structure of the balance sheet and the presentation of items. EBIT: Earnings before interest and Taxes; EBT: Earnings before taxes

Studies on the impact of accounting standards on financial analysis such as Fülbier et al. (2008) following Goodacre (2003) and Fitó et al. (2013) indicate that financial ratios do not follow a normal distribution; therefore, the authors use non-parametric tests to identify significant statistical differences between the ratios before and after the capitalization. In our sample, financial ratios also do not follow a normal distribution; therefore, we run non-parametric Wilcoxon tests to check for significant differences in the ratios' means before and after operating leases capitalization. 


\section{Results}

To look for significant differences in the means of the ratios before and after operating leases capitalization we run non parametric Wilcoxon tests.

Table 5 shows the impact on financial ratios expected of the operating lease proposal. For the financial ratios, we show the Wilcoxon test results below.

Table 5: Expected impact for key financial ratios $(\mathrm{N}=64)$.

\begin{tabular}{|c|c|c|c|c|c|}
\hline & & Before & After & Diff. & $\begin{array}{c}\text { Wilcoxon } \\
\text { Test }\end{array}$ \\
\hline \multirow[t]{2}{*}{ LEV1 } & Mean & 0,562 & 0,607 & 0,045 & $\begin{array}{l}6,955 * * * \\
(0,000)\end{array}$ \\
\hline & SD & 0,184 & 0,216 & 0,054 & \\
\hline \multirow[t]{2}{*}{ LEV2 } & Mean & 1,097 & 0,994 & $-0,103$ & $\begin{array}{l}-6,955^{* * *} \\
(0,000)\end{array}$ \\
\hline & SD & 1,281 & 1,263 & 0,116 & \\
\hline \multirow[t]{2}{*}{ LEVQ } & Mean & 0,861 & 0,655 & $-0,206$ & $\begin{array}{l}-4,755^{* * *} \\
(0,000)\end{array}$ \\
\hline & SD & 0,906 & 0,631 & 0,423 & \\
\hline \multirow[t]{2}{*}{$\begin{array}{l}\text { LIQ } \\
\end{array}$} & Mean & 0,837 & 0,775 & $-0,062$ & $\begin{array}{l}-6,955^{* * *} \\
(0,000)\end{array}$ \\
\hline & SD & 0,420 & 0,431 & 0,067 & \\
\hline \multirow[t]{2}{*}{ NCAT } & Mean & 2,983 & 0,135 & $-2,847$ & $\begin{array}{l}-6,935^{* * *} \\
(0,000)\end{array}$ \\
\hline & SD & 2,454 & 0,3463 & 2,546 & \\
\hline FINLEV & Mean & 6,072 & 9,121 & 3,049 & $\begin{array}{l}7,987 * * * \\
(0,000)\end{array}$ \\
\hline
\end{tabular}




\begin{tabular}{|l|l|c|c|c|c|}
\hline & SD & 21,785 & 32,468 & 12,316 & \\
\hline ROA & Mean & 0,0371 & 0,0334 & - & $-5,363^{* *}$ \\
& & & & 0,0036 & $(0,000)$ \\
\hline
\end{tabular}

Table 5: Expected impact for key financial ratios $(\mathrm{N}=64)$.

Overall, Table 5 shows that a very significant impact on hotels' financial ratios - and therefore, following the literature, on their capital structure, firm performance, viability, and reputation - is expected. Leverage ratios show a significant impact (i.e. increase of indebtedness); as operating leases play a key role in the lodging industry, we expected this result. Values obtained for the ratios of leverage (LEV1) and financial leverage (FINLEV) are higher after the operating lease capitalization. Leverage (LEV1) has increased $7 \%$ on average and financial leverage (FINLEV) $23.7 \%$. On the contrary, the second leverage ratio (LEV2), the quality of debt (LEVQ), and the liquidity ratio (LIQ) show lower values after capitalization, also as expected. The second leverage ratio (LEV2) has decreased substantially due to the impact on equity. Debt quality has decreased $27.5 \%$ on average due to the impact on non-current liabilities. If lease future payments are included as debt, we observe that debt indicators together with liquidity indicators confirm hotels' worse financial situation after capitalization.

The non-current assets turnover has also diminished considerably due to the impact of newly considering leased assets as part of hotels' non-current assets. This ratio refers to hotels' asset management: the higher the ratio, the better the turnover of the assets being considered. If lease contracts were included in the balance sheet, the total investment represented by total assets would be much higher for the same level of sales, resulting in a poorer performance for the assets in the firm.

When we analyse the performance ratios by means of the most relevant profitability ratios, we also find significance for both ROE and ROA. The latter, for example, decreases $10 \%$ due to the increase in the total assets derived from capitalization. This means that the proposal not only affects the presentation of items in the balance sheet and static measures such as gearing but also the 'real' performance of the company (i.e. ROA) and the return for shareholders (i.e. ROE). It is important to note here that, even with the assumed $50 \%$ of residual life over the total life of the contracts, there is still a significant effect on profitability, which, as studies show, can lead to negative effects on growth (Madan, 2007). 
These results confirm our hypothesis (H1), as we see a significant change in most ratios. Our results support the evidence offered in general studies such as Fülbier et al. (2008) in Germany and Beattie et al. (1998) in the UK. It also helps us understand the concerns of the lodging industry as reflected in the comment letters sent to regulators. This sector knows that this is an important issue that can lead to unexpected and sometimes undesirable consequences. 


\section{Conclusions, Policy Implications and Study Limitations}

In this paper, we have analysed the economic consequences for hotels of operating leases capitalization using both hotel operators' comment letters and an analysis of their financial statements. We have described hotels' perceptions of the proposal and compared them with the impact predicted using an empirical analysis of key financial ratios.

Analysing the comment letters reveals how hotels have actively lobbied against the proposal by arguing that its negative effects will affect both the informational and contractual characteristics of their financial reporting. Our first conclusion thus refers to the intended and unintended consequences of accounting standards as derived from our perceptions analysis. Regarding the intended consequences, we have observed that, although regulators issue new proposals that are expected to have positive effects on the qualitative characteristics of financial information, hotels do not perceive them to be positive. Hotels predict a worsening of comparability, reliability, and consistency together with an increase in subjectivity. Regarding the unintended consequences, our analysis of the comment letters confirms our expectation, as hotels believe the proposal will damage their financial performance. They expect an increase in their debt positions together with less availability of credit and problems regarding debt covenants. As for income measures, they expect negative effects on profitability and volatility. Overall, the hotels perceive negative effects on economic and financial performance after capitalization.

The empirical analysis of the expected impact of considering future lease payments as debt finds significant effects on ratios as important as those related to debt and performance, indicating that ignoring those payments in the computation of debt is important to the analysis of hotels' financial statements. Debt and liquidity indicators, together with profitability measures, would be substantially affected should those payments be considered as debt. The effect on gearing ratios is particularly important, as this could seriously affect debt covenants, hotels' financial position, and, in the end, their reputations.

Overall, the results show that the perception of the industry as shown in its lobbying is confirmed by the empirical analysis of the expected impact on key financial ratios. This study is an ex ante research and thus cannot go beyond the effect analysis (perceived vs. expected) of this new standard. However, if a perceptions analysis (qualitative), together with an expected impact assessment (quantitative), shows an effect on debt positions and financial performance, we can expect relevant implications for the industry. The literature 
shows that financial metrics and the balance in the capital structure regarding debt and equity can affect performance and future strategy. If operating leases' future payments are incorporated as debt, hotels' capital structures will be modified. Madan (2007) states that capital structure is an important determinant of a firm's success and that different capital structures call for different growth strategies in the lodging industry. In this sense, changes in debt indicators may have an impact on future hotel strategies. For example, some players in the industry have explicitly stated their intention to reduce the relative weight of operating leases (ACCOR, 2012) in favour of HMA or franchises.

The literature shows that leases have increased substantially in the hotel industry because of their flexibility, as noted in the letters. If the proposal is implemented and operating leases are recorded as assets and debt, hotels may change their strategy and alter the increasing trend in lease use. Alternative options like hotel management agreements (HMA) may be substituted for operating leases; HMAs offer several benefits, such as the opportunity for an inexpensive and rapid expansion and a low downside risk. However, operators do not enjoy the residual benefits of ownership and do not capitalise on the value created (Lelacqua and Smith, 2012); moreover, the agreement can be terminated at any time by the owner. These disadvantages may not be a concern, however, if operating leases are capitalized and considered as debt. Of course, access to HMA depends not only on the operator but also on the owner. However, if there is an option, trends in growth strategies may be modified.

To conclude, hotels and managers should assess the impact of the proposed changes on their financial performance and plan to operate under the new rules. Both the studied hotels and others will need to understand and be able to measure the rules' effect so that future strategies regarding capital structure, profitability, and growth can be adequately planned and sustained.

Our study has several limitations relating to its assumptions. We have made assumptions regarding the interest rate and the life of the leases' contracts. However, and in order to provide our results with more robustness, we have conducted sensitivity analyses that consider various measures for the interest rate and different percentages of useful life over total life. We have added one and two points to the interest rate (the higher the rate, the lower the impact), and we have considered several scenarios concerning the proportion of residual life versus total life. In all cases, the results are similar.

A second limitation is the lack of information available for some of the European hotels examined. This lack of disclosure is not particular to the sector, as the literature shows 
that companies do not always fully comply with accounting standards requirements. It is expected that hotels' level of disclosure increase over time.

In future research, we will try to expand the sample in the number of hotels and years of analysis. The same analysis could be applied to other sectors presumably more affected by this new rule regarding their financial behaviour or specific debt characteristics 


\section{REFERENCES}

Beattie, V., Edwards, K., \& Goodacre, A. (1998), "The impact of constructive operating lease capitalization on key accounting ratios", Accounting and Business Research, 28, 233-254.

Beck, A.C., Campbell, D., \& Shrives, P.J. (2010)," Content analysis in environmental reporting research: Enrichment and rehearsal of the method in a British-German context", The British Accounting Review, 42(3). 207-222.

Bennet, B, \& Bradbury, M. (2003), "Capitalizing non-cancellable operating leases", Journal of International Financial Management and Accounting, 14, 101-114.

Brüggemann, U., Hitz, J.M., \& Sellhorn, T. (2013), "Intended and Unintended Consequences of Mandatory IFRS Adoption: A Review of Extant Evidence and Suggestions for Future Research", European Accounting Review, 22(1), 1-37.

Dalbor, M.C., \& Upneja, S. (2004), "The investment opportunities and the long-term debt decision of US lodging firms", Journal of Hospitality \& Tourism Research, 28(3), 346355.

Depoers, F., \& Jeanjean, T. (2012), "Determinants of quantitative information withholding in annual reports", European Accounting Review, 21(1), 115-151.

Ely, K. (1995), “Operating lease accounting and the market's assessment of equity risk", Journal of Accounting Research, 33, 397-415.

Fito, M.A., Moya, S., \& Orgaz, N. (2013), "Considering the impact of operating leases in key financial ratios", Spanish Journal of Finance and Accounting, 159, 341-368.

Fülbier, R., Lirio, J., \& Pferdehirt, M., (2008), "Impact of lease capitalization on Financial ratios of Listed German Companies", Schmalenbach Business Review, 60, 122-144.

Gallizo, J.L. (2005), “Avances en la investigación de los ratios financieros. La dinámica de los ratios", Revista de Contabilidad y Dirección, 2, 123-148.

Georgiou, G. (2004), "Corporate Lobbying on Accounting Standards: Methods, timing and perceived effectiveness", Abacus, 40(2), 219-237.

Giner, B., \& Arce, M. (2012), "Lobbying on accounting standards: Evidence from IFRS 2 on share-based payments", European Accounting Review, 21(4), 655-691.

Goodacre, A. (2003), "Operating lease finance in the UK retail sector", International Review of Retail, Distribution and Consumer Research, 20, 49-66.

Harrison, J.S. (2003), "Strategic Analysis for the Hospitality Industry", Cornell Hotel and Restaurant Administration Quarterly, 44, 139-152. 
Hernandez-Lara, A.B., Campa-Planas, F., \& Sanchez.Rebull, M.V. (2012), "Categorizing the Spanish accommodation sector: Does firm size influence economic profitability?" Cornell Hospitality Quarterly, 53 (3), 257-264

Hesford, J.W., \& Potter, G. (2010), “Accounting Research in the Cornell Quarterly: a review with suggestion for future research", Cornell Hospitality Quarterly, 51(4), 502512.

Imhoff, E., Lipe, R., \& Wright, D., (1991), “Operating leases: impact of constructive capitalization”, Accounting Horizons, 5, 51-63.

Imhoff, E., Lipe, R., \& Wright, D., (1997), "Operating leases: income effects of constructive capitalization", Accounting Horizons, 11, 12-32.

International Accounting Standards Board, (2010), Leases, IAS Number 17.

International Accounting Standards Board, (2010), Accounting for Leases, Exposure draft. ED 2010/9.

International Accounting Standards Committee Foundation, (2008), Due process handbook of the IASB.

Jung, H.I. (2008), "WACC as touchstone performance indicator: the use of financial ratios as performance indicator", From operations to capital investments, 20(6), 700-710.

Koh, J.H., \& Jang, S.C. (2009), "Determinants of using operating lease in the hotel industry", International Journal of Hospitality Management, 28 (4), 638-40.

Lelacqua, L., \& Smith, T. (2012), “To Lease or not to Lease? HVS Consulting and Valuation", London.

Madan, K. (2007), "An analysis of the debt-equity structure of leading hotel chains in India", International Journal of Contemporary Hospitality Management, 19(5), 397-414.

Parte, L., \& Alberca, P. (2013), "Determinants of technical efficiency in the Spanish hotel industry: regional and corporate performance factors", Current Issues in Tourism.

Robinson, J., Xue, Y., \& Yu, Y. (2011), "Determinants of disclosure non-compliance and the effect of the SEC review: evidence from the 2006 mandated compensation disclosure regulation", The Accounting Review, 86(4), 1415-1444.

Schipper, K., (1994), "Academic accounting research and the standard setting process", Accounting Horizons, 8(4), 61-73.

Singh, A., (2010), "Proposed lease accounting changes: Implications for the restaurant and retail industries", Journal of Hospitality \& Tourism Research, 36, August.

Street, D., \& Gray, S. (2001), "What lies behind non-compliance?" Accounting and Business, July-August, 36-37. 
Street, D., \& Gray, S. (2002), "Factors influencing the extent of corporate compliance with IAS: summary of a research monograph", International Accounting, Auditing and Taxation.

Tsai, H., Pan, S., \& Lee, J. (2011), "Recent research in hospitality financial management", International Journal of Contemporary Hospitality Management, 23(7), 941-971.

Upneja. A., \& Dalbor, M. (2001), "The choice of long term debt in the US lodging industry", UNLV Journal of Hospitality, Tourism and Leisure Science, available at: http: //hotel. Unlv.edu/res_journalpubsarticle.html.

Weber, R.P. (1990), Basic Content Analysis, (Second Edition). Newbury Park, CA: Sage.

Whittaker, C. (2008), "Hotel operator motives in UK sale and leaseback/managementback transactions", International Journal of Hospitality Management, 27(4), 641-8.

Yen, A., Hirst, E., \& Hopkins, P. (2010), “A content analysis of the comprehensive income exposure draft comment letters", Research in Accounting Regulation, 19, 53-79.

Zeff, S.A. (1978), "The rise of "economic consequences", Journal of Accountancy, December, 56-63. 
Economic consequence of accounting standards in the hotel industry: lobbying arguments versus expected impact 
Núria Arimany, Àngels Fitó and Neus Orgaz-Guerrero 
Economic consequence of accounting standards in the hotel industry: lobbying arguments versus expected impact 
Núria Arimany, Àngels Fitó and Neus Orgaz-Guerrero 